\title{
THE CONCEPT OF COLLECTIVE INVESTMENT INSTITUTION AND SPECIFIC TAX ADVANTAGES PROVIDED FOR THESE INSTITUTIONS IN TURKEY
}

\author{
Filiz KESKIN ${ }^{1}$
}

\begin{abstract}
In this paper, the concept of collective investment institution and the regulations in Turkey that are in the Capital Markets Legistation intended for these institutions will be outlined, and tax advantages provided for collective investment institutions and investors and problems and suggestions occurred in the application will be discussed. The importance of collective investment institutions operating in the world under 3 legal structures, namely investment company, trust and contractual model to enable investors with low savings to operate in the financial markets has gradually increased in the countries' economies. In Turkey, according to regulations in Capital Markets Legislation, collective investment institutions operate in two legal structures, namely investment companies and investment funds. Advantages provided to these institutions and investors in our tax legislation are as follows: For investors; participation income exemption in Article 5 and deduction in venture capital fund in Article 10 of Corporate Income Tax Law; deduction in venture capital fund in Article 89 of Income Tax Law; non-declaration of incomes and \% 0 rate of withholding tax for income obtained from participation certificates and stocks of some funds and companies in Provisional Article of 67, forcollective investment institutions; exception of portfolio management or corporate profits in Article 5 and \%0 rate of withholding tax for exempted profits in Article 15 of Corporate Income Tax Law; \%0 rate of withholding tax for exempted profits and no withholding tax for some incomes in Provisional Article of 67 of Income Tax Law, exception of BITT for the money and capital market profits of some institutions in Law on Taxes on Expenditure, exceptions of stamp tax for some papers in Stamp Tax Law. In conclusion, recommendations will be given as such; preparation of clear regulations regarding the provisions providing tax advantages to collective investment institutions, expansion of the scopes of existing tax benefits; applying no withholding tax to incomes derived by some institutions from their assets and transactions in order to avoid creating more costly result than investor's direct investment, making regulations in respect of exceptions concerning Value Added Tax, Title Fees and Real Estate Tax for some investment fund and companies.
\end{abstract}

Keywords: Collective, Investment, Institution, Fund, Company, Tax

JEL Code: G23, H2O, K34

\section{Introduction}

The purpose of collective investment institutions is to direct the savings of small savings holders who do not have the necessary knowledge to invest in financial markets, hesitate to invest in these markets due to the risks and do not have the opportunity to invest in various investment instruments due to their low savings to financial markets.

Therefore, the investment instruments in which big capital owners have the opportunity to invest also become available for small investors by minimizing the risks through professional institutions.

\footnotetext{
1 Prof., İstanbul Arel University, filizkeskin@arel.edu.tr, av.filizkeskin@gmail.com
} 
The importance of collective investment institutions has increased gradually in financial markets and national economies around the world, and the shares/stocks of these institutions have become the one of the preferred investment instruments. Moreover, in the historical development process, different types and structures of collective investment institutions started to operate in line with the needs of investors and markets.

Therefore, arrangements have also been made in Turkey to provide tax advantages for both collective investment institutions and investors.

The subject of this paper consists of the concept of collective investment institution and the general provisions of Capital Market Legislation for investment funds and companies, which are collective investment institutions operating in our country, explaining the regulations that provide tax advantages (exception, deduction, \%0 tax rate, non-declaration) for collective investment institutions and their investors in our tax legislation and evaluating the problems encountered in practice and giving suggestions about this issue.

\section{Concept of Collective Investment Institutions (CII)}

With a general definition collective investment institution (CII) generally refers to incorporated companies or unincorporated undertakings that invest in financial assets (mainly marketable securities and bank deposits) and/or non-financial assets using the funds collected from investors by means of issuing shares/units (OECD, 2008: 192).

It is seen that CII can be established under three different legal framework, namely investment company, trust and contract model (HAFEEZ, 2015: 152).

The first establishment in the world, similar to today's CII, is The Foreign \& Colonial Goverment Trust, founded in 1868 in the UK. The purpose of the fund in the certificate of formation was indicated as;

"To provide the investor of moderate means the same advantage as the large capitals in diminishing risk... by spreading the investment over a number of stocks" (St. GILES and others, 2003: 14)

The EU issued a directive on the collective investment models on the Undertakings for Collective Investments in Transferable Securities - UCITS (CMB, 1997: 17)Furthermore, various studies are being carried out for CIl within OECD (OECD, 2001: 10)

\section{Collective Investment Institutions in Turkey}

According to Article $3 /(\mathrm{m})$ of the Capital Market Law (CML);

Cll are investment funds and investment companies.

"Investment funds" in Article 52 of CML is defined as;

"the asset which is established by portfolio management companies within the fund rules in conformity with the fudiciary ownership ${ }^{2}$ principles on the account of the savers, with money or

2 About this concept see: OĞUZMAN-ÖZ, 2018: 133 
other assets gathered from savers pursuant to the provisions of this Law in return for fund units in order to operate the portfolio or portfolios consisting of instruments and rights determined by the Board and which does not have a legal entity..."

The types of investment funds can be listed as; securities, stock market, real estate, venture capital and pension investment funds.

"Investment companies" in Article 48 of CML are defined as;

"...joint stock corporations with fixed or variable capital established in order to issue their shares and with the purpose of managing the portfolios comprised of capital market instruments, real estates, venture-capital investments and other assets and rights to be determined by the Board"

The types of investment companies can be classified as; securities, real estate and venture capital investment companies.

\section{Tax Advantages Specific to the Collective Investment Institutions in Turkey}

\subsection{Corporate Income Tax Law (CITL)}

In accordance with article 5 of the CIT Law,

"The dividends obtained from participation shares of resident venture capital investment funds and stocks of resident venture capital investment companies"

are exempt from CIT. (CITL art. 5-1-a-3)

Also according to Article 5 of $\mathrm{CITL}$;

-profits derived from portfolio management of securities investment funds or companies established in Turkey and investment funds or companies whose portfolio traded on a stock exchange established in Turkey based on gold and precious metals,

-income of pension investment funds, venture capital and real estate investment funds or companies

are exempt from CIT.(CITL art. 5-1-d)

However, if aforementioned institutions have other incomes not qualifying for exception, those incomes are subject to CIT.

In Article 15-(3) of CITL; It is stated that;

"barring incomes of pension investment funds, a \%15 withholding is made within the corporation from the incomes (whether distributed or not) stated in subparagraph (d) of paragraph 1 of Article 5 of the Law."

However, with Council of Ministers Decision (CMD) No. 2009/14594, withholding tax rate is $0 \%$. In terms of foreign investment funds, tax advantages are provided in Article 5 / A of CITL in case of certain conditions.

According to Article 10/g of the CITL, the portion (not exceeding $\% 10$ declared income) of the 
amount allocated as venture capital fund in Article 325/A of the Tax Procedure Law (TPL) can be deducted from the tax base.

\subsection{Income Tax Law (ITL)}

In Article 89/12 of ITL, there is a provision stipulating a deduction of venture capital fund in terms of income tax according to Article 325/A of TPL.

On the other hand Provisional Article 67 of ITL requires taxation by means of withholding for security incomes, which are as follows:

- In paragraph 1, trading income of the stocks and bonds, bond interest, incomes of investment fund share and lending income,

- In paragraph 2, excluding the payments to banks or brokerage houses or to other real persons and legal entities through banks, security incomes (all kinds of bonds, treasury bill interests) stated in Article $75 / 5$ of ITL,

- In paragraph 3, banks and brokerage houses to acquire a security or other capital market instrument without being subject to withholding tax under paragraph (1),

- In paragraph 4, security capital incomes stated in subparagraphs of 7 (deposit rates), 12 (for example, dividends paid to creditors not charging interest, and dividends paid for profit and loss share certificates) and 14 (repo / reverse repo revenues)

are subject to $\% 15$ withholding tax.

The tax advantages of this article will be explained under the following headings:

\subsubsection{Tax Advantages Specific to Collective Investment Institutions}

In Provisional Article of 67/5 of ITL, it is stated that in accordance with the provisions of paragraphs (1) and (4), no withholding tax will be made from revenues of exchange traded funds and pension investment funds established according to CML.

With CMD No. 2006/10731,

- withholding tax rate was determined as $\% 0$ for the incomes of some funds and companies stated in paragraphs (1), (2), (3) and (4) of Provisional Article 67. These are;

- stock exchange investment funds

-security investment funds and companies established in accordance with CML.

According to Provisional Article 67/8 of ITL, incomes (whether distributed or not) of security investment funds (including exchage traded funds) and companies established in accordance with $\mathrm{CML}$ that are exempt from $\mathrm{CIT}$, are subject to $\% 15$ withholding tax.

However, with CMD No. 2006/10731, this rate was determined as $\% 0$. 


\subsubsection{Tax Advantages Specific to Investors}

Within the paragraph 1 of Provisional Article 67 of ITL, incomes of investment funds share and profits of investment companies on stock trading are subject to withholding tax. ${ }^{3}$

However, the rate of withholding tax for incomes of resident and non-resident corporations under the specified paragraph (hence incomes of investment funds share and profits of investment companies on stock trading) is determined as $0 \%$.

The withholding tax rate for resident and non-resident individuals' incomes of investment funds share and profits of investment companies stock trading is determined as $\% 10$.

The incomes derived from the disposal of participation certificates held more than a year is out of the scope of withholding tax if 51\% of the portfolio of the investment fund is continuously invested in the stocks traded in BIST. (ITL Prov.67/1)

With CMD No. 2012/3141, the incomes obtained by resident and non-resident individuals, which are;

- Shares of stock-intensive funds

- Profits derived from the disposal of real estate and venture capital investment companies

are subject to $\% 0$ withholding tax.

\subsection{Law on Taxes on Expenditure (BITT)}

Securities and venture capital investment funds and companies and pension investment funds are considered as BITT taxpayers as they fall into the banker's definition because they perform the activities specified in Article 28 of Law No. 6802 as the main subject of the activities. Other transactions of the mentioned institutions are not subject to BITT. ${ }^{4}$

In Article 29/t of the Law, the money obtained as a result of the transactions made in money and capital markets by pension investment funds, security investment funds and companies, and venture capital investment funds and companiesare exempt from BITT.

Since the main subject of real estate investment funds and companies is not trading securities or capital market instruments, these institutions do not have any liability for BITT. ${ }^{5}$

\subsection{Stamp Tax Law (STL)}

In Table 2 (of subparagraphs IV -16, 21 and 50. and subparagraph 21) on exceptions in STL, there are exception regulations for documents concerning some transactions of investment funds, pension investment funds, real estate investment funds and companies, and venture capital investment funds and companies.

\footnotetext{
3 Dividends of investment company stocks will be taxed in accordance with the general provisions of the ITL and CITL (as it is not covered in Provisional Article 67 of the Income Tax Law).

4 The transactions of these institutions under the scope of BITT are exempt from VAT according to the article 174-e of VATL. Other transactions are subject to VAT.

5 Real estate investment funds and companies are VAT taxpayers.
} 


\section{Conclusion}

In article 5 of $\mathrm{CITL}$, incomes derived from venture capital investment funds and companies and corporate profits or profits obtained from portfolio management of investment funds and companies based in Turkey are exempt from CIT.

In terms of foreign investment funds, regulations are made to provide tax advantages in case of existence of the conditions stated in Article 5/A of CITL.

Additionally, withholding tax rate for the income of investment funds and companies exempted from $\mathrm{CIT}$ is determined as $0 \%$ in Article $15 / 3$ of CITL.

In Provisional Article 67 of ITL, tax advantages (such as exclusion from withholding tax, nondeclaration right and $0 \%$ tax rate) are provided to corporate profits of investment funds and companies, to some incomes and revenues within the article some of their income and to investors of these institution.

In articles 89 of ITL and 10 of CITL the amount allocated as venture capital funds in article 325/A of TPL can be deducted at certain rates.

Besides, tax exceptions are regulated for the development of certain CII in Turkey within Law on Taxes on Expenditure and STL.

In cases where the provisions providing tax advantages for $\mathrm{Cll}$ are not sufficiently clear (such as, the portfolio structure of funds to be exempted from tax and the nature of the papers to be exempted), as the tax administration seems to have a narrow interpretation of their scope, the legislator needs to explicitly write these provisions.

It is recommended that the scope of existing tax advantages for $\mathrm{Cll}$ and investors should be extended, all of the profits and revenues obtained from the transactions and the assets in portfolio of these institution should be excluded from withholding tax and thereby a more costly result will not be caused than the direct investment of the investor. Regulations for VAT, title fees and real estate tax exceptions for some investment funds and companies can also be recommended.

\section{References}

Hafeez, M. M. (2015). Corporate Governance and Institutional Investment, Florida, UniversalPublishers.

OECD. (2008), Benchmark Definition of Foreign Direct Investment, Fourth Edition.

OECD. (2001). Governance System for Collective Investment Scheme in OECD Countries, J. K. Thompson \& Sang-Mok Choi.

Oğuzman, M., Öz, K. \& Turgut, M. (2018). Borçlar Hukuku Genel Hükümler, Cilt: 1, 16. Bası, İstanbul, Vedat Kitapçılık.

Sermaye Piyasasi Kurulu. (1997). Menkul Kıymetler ve Borsalarla Ilgili Avrupa Topluluğu Düzenlemeleri (Direktifler-Direktif Teklifleri-Ortak Tavırlar) Redaksiyon, Bahşayış Temir, Ağustos, Yayın No: 85. 
St. Giles, Alexeeva, Buxton. (2003). Managing Collective Investment Funds, Second Edition, England, John Wiley \& Sons Ltd.

www.spk.gov.tr.

www.gib.gov.tr. 